\title{
Black Educational Activism for Community Empowerment: International Leadership Perspectives
}

\author{
Camille Wilson \\ University of Michigan \\ U.S.A. \\ Lauri Johnson \\ Boston College \\ U.S.A.
}

\begin{abstract}
This article discusses themes emerging from studies of Black educational activism conducted in London, Toronto, and Detroit. An analysis of narrative data reveals that Black educational activists resist racism and other forms of oppression; act as border crossers and/or boundary spanners as they navigate complex communitybased, institutional, and political terrains; serve as change agents from the grassroots to institutional level; and develop and enact distinct types of social capital to yield community versus individual uplift. The authors conclude that activists should be valued as leaders and strategically engaged in K-12 public school systems to combat racism and build effective school-community alliances.
\end{abstract}

KEYWORDS: Black activism; border crossing; boundary spanning; institutional activism; social capital

\author{
Conceptual Framework \\ Methodological Approach and Overview of Findings \\ Profiles of Black Educational Activism across the Westernized African Diaspora \\ Discussion and Recommendations \\ Notes \\ References \\ Author Contact
}

The work of dismantling structural racism in education demands bold, strategic, and sometimes revolutionary acts that, by their nature, conflict with mainstream, lauded approaches to educational leadership (Murtadha \& Watts, 2005; Perlstein, 2005; Richards \& Lemelle, 2005). Public educational leadership is often conceptualized as the sole terrain of professional educators who hold administrative positions or other posts vested with high levels of institutional authority. Such notions of leadership validate the initiative and influence of middle-to-upper income, formally educated, system insiders, the majority of whom, in Western nations, are White and male (Alston \& McClellan, 2011). Dominant leadership models therefore fail to affirm non-Westernized leadership traditions and those deriving from people of color, which are often community-oriented and/or more collaborative than hierarchical (Franklin, 1990; Jean-Marie, Williams, \& 
Sherman, 2009). These dominant models also lack cultural relevancy to many racially, ethnically, and linguistically diverse populations and do not adequately address critical issues of racism or social justice (Shoho, Merchant, \& Lugg, 2005). Educational activism, which is frequently enacted by sizeable populations of systemic outsiders and people of color, is devalued and under-recognized as a form of leadership, yet has been a pivotal activity for Black community members to resist structural racism in public educational systems and strive for systemic change (Johnson, 2013; Perlstein, 2005).

In this article, we offer an analysis of themes emerging from qualitative and historical studies of Black educational activism conducted in three major international urban locales across a 40-year period: London in the 1970s and 1980s, Toronto in the 1980 s and 1990s, and Detroit in the 2000s. Each of the cities has sizeable populations of Black citizens and, at various times, has had school districts intensely affected by equity gaps and student achievement disparities, widely contested district governance, and political turmoil and civil unrest related to racial inequality that have influenced activists' goals and efforts. Building upon Williamson's (2005) scholarship on Black educational activists' community control efforts, we define activism as work done by public citizens to resist the discriminatory and marginalizing effects of dominant power structures and institutions like public schools in order to work towards institutional, social, and societal improvement.

Findings affirm that the educational arena has been and continues to be a crucial site of political resistance for Black community members who traditionally regard educational attainment as a tool for political liberation and socioeconomic advancement despite the systemic educational inequities that routinely impair Black youth (Richards \& Lemelle, 2005; Wilson, Douglas, \& Nganga, 2013). Black educational activists across locales and time periods engage in activism to resist racism and other forms of oppression; act as border crossers and/or boundary spanners as they navigate complex community-based, institutional, and political terrains; serve as change agents from the grassroots to institutional level; and, develop and enact distinct types of social capital to yield community versus individual uplift.

Educational activists are leaders who contribute to and protect democratic education through their use of grassroots strategies outside of school systems and by their professional savvy within. Their varied strategies challenge structural racism in schools and advocate for children in their communities. Hence, we suggest why and how activists should be more respectfully and strategically engaged to combat racism and build effective school-to-community alliances that improve education for marginalized students.

\section{Conceptual Framework}

Our conceptual framework was informed by four key interrelated strands of scholarship: (a) educational advocacy and activism (Johnson, 2013; Loder-Jackson, 2011; Williams, 2009), (b) Black feminist theory (Collins, 1990; Henry, 2005), (c) Black protest politics (Perlstein, 2005; Richards \& Lemelle, 2005; Williamson, 2005), and (d) 
culturally relevant/responsive leadership (Alston, 2005; Dillard, 1995; Franklin, 1990; Johnson, 2006; Murtadha \& Watts, 2005). Work in these areas supports the idea that educational arenas are crucial sites of Black advocacy, protest, and resistance, thereby forming a foundation for educational activism as leadership.

Furthermore, research suggests that many Black communities have traditionally regarded educational attainment as a tool for political liberation and socioeconomic advancement despite systemic issues related to inequitable educational access, instruction, and resources that routinely undermine the quality of public education offered to Black youth and threaten their chances for life success (Richards \& Lemelle, 2005; Wilson, Douglas, \& Nganga, 2013). Consequently, there are Black families and communities across the African Diaspora who have long engaged in activism and protest politics to effect educational improvement (Johnson, 2013). Indeed, studies of the change efforts of Black families, community organizers, and professional educators indicate that such activism and protest have been enacted by Black men and women across generations and locales (Johnson, 2013; Loder-Jackson, 2011; Marshall \& Anderson, 2009; Williams, 2009).

We assert that such activism also constitutes educational leadership that challenges the domineering and racist status quo.1 As Watkins (2005) explained, throughout time "Black protest has ranged from silent prayer to urban warfare" (p. 1). In addition, Collins (1990, p. 746), in her seminal explication of Black feminist thought, validated the notion that "everyday acts of resistance" can contribute to communal, institutional, and/or societal transformation in the midst of interlocking racial, class, and gender oppressions. Historical and contemporary activism has involved Black communities exerting their voices and participating in a range of democratic activities: "speaking truth to power" in town hall forums, school board meetings, or via legislative testimony; organizing marches and strikes to protest racist treatment; and creating alternative community-based educational sites that center Black students and their families in their history and culture. Such Black activism complements theories of transformative and transformational leadership that highlight the efforts of leaders who are willful and risk-taking change agents attempting to make schools more socially just (Alston \& McClellan, 2011; Cooper, 2009; Dantley \& Tillman, 2009; Shields, 2000).

\section{Methodological Approach and Overview of Findings}

We took a fresh look at narrative data from three qualitative and historical studies of Black educational activism in London, England, Toronto, Canada, and Detroit, U.S.A., to consider three questions about educational activism and leadership across the studies:

1. Why and how do Black educational activists engage in resisting public educational systems in their community?

2. What organizing and advocacy strategies do activists use as part of their efforts to improve public schools and why?

3. How can such strategies inform K-12 public school improvement efforts? 
Findings from the London and Toronto research stem from two historical case studies the second author of this article conducted, which drew upon archival data and 20 oral history narratives conducted with parents, educator-activists, and community members at large. The Detroit research stems from an in-depth, qualitative interview study the first author conducted that yielded approximately 32 hours of data from eight educational activists. These activists were Black parents, educators, and community members at large.2

As part of the original research, interview transcripts in all three contexts were fully transcribed, read multiple times, and coded multiple times to identify themes. Interviewees were also consulted during the original studies to help verify our analyses. In each study we drew upon narrative data from in-depth interviews and life history contexts; used purposeful, snowball sampling (Creswell, 2008); considered historical and contemporary contexts of Black activists' perspectives and change efforts; and, involved both non-professional and professional K-12 educators whose work fell along a subtle to radical activist continuum. These methodological similarities facilitated and helped justify the appropriateness of our cross-study comparison of narrative data.

Mindful of the distinct historical, contemporary, intercultural, and geographic contexts, we were still able to pinpoint four shared findings. First, Black activists across locales worked to counteract the effects of educational inequity given their critical consciousness about the impact of structural racism and micro-to-macro level oppression. While there were individual differences in tactics and strategies based on the historical period and the "politics of place" (McKittrick \& Woods, 2007), activists shared an understanding of how institutional racism affected the educational realities and life chances of Black youth in all three sites.

Second, they skillfully navigated complex community-based, institutional, and political terrains as border crossers (Giroux, 2005; Wilson, Ek, \& Douglas, 2014) and/or boundary spanners (Miller, 2007, 2008, 2009). Border crossing, from sociological and epistemological standpoints, entails traversing physical and/or conceptual landscapes where one must negotiate notions of sociocultural difference and varying power dynamics (Wilson, Ek, \& Douglas, 2014). While sometimes marked by physical barriers and/or institutional boundaries, borders are often powerful ideologically and socially constructed spaces of division (Giroux, 2005). On the other hand, boundary spanning refers to how leaders span professional settings to leverage bureaucratic change and build new and nontraditional partnerships that further school district initiatives (Honig, 2006; Jemison, 1984; Tushman, 1977). Miller (2007; 2008; 2009) explains that more socially conscious boundary spanners draw upon contextual knowledge, interpersonal skills, trust, and a sense of connectedness and community loyalty to strengthen communities as well.

Third, Black activists served as influential change agents from the grassroots community level to the professional and political institutional level. As Loder-Jackson (2011) also found in her cross-generational study of African American educators' activism, the educational activists we studied pursued varied paths of resistance toward similar goals. Some engaged in grassroots, public protest activities like those prominent during the US civil rights era, while others pursued quieter, yet still courageous, changeoriented measures implemented within institutions. 
Last, the activists we studied developed and activated distinct types of social capital to yield collective racial and community uplift rather than individual mobility. While social capital is commonly conceived of as the social assets, relationships, and networks used to increase one's status and socioeconomic advancement, scholars like Stanton-Salazar (2011) describe how some institutional agents and authority figures within education intentionally use and expand social capital for the collective empowerment of youth. Moreover, scholars of Black protest theory and Black feminist thought emphasize how collective empowerment and uplift goals have historically motivated many Black community members (both professionals and non-professionals) to engage in political resistance (Collins,1990; Perlstein, 2005; Richards \& Lemelle, 2005; Williamson, 2005). While prominent theorists across Black political and cultural studies domains have emphasized the value of Black activism and liberation movements, there is a dearth of educational leadership scholarship that marshals empirical data related to Black activism and also considers comparative contexts. 3 We therefore offer our cross-comparative study to help bolster such analyses and highlight the globalized plight of many African descendants seeking high quality and equitable educational reform.

\section{Profiles of Black Educational Activism across the Westernized African Diaspora}

The brief profiles of Black activists in London, Toronto, and Detroit that follow offer representative snapshots from our larger studies and highlight the unique contexts and shared findings relevant to their Western locales.

\section{London in the 1970s and 1980s}

Although there has been a Black presence in Britain since the 16th century, the great wave of post-war migration from the Caribbean to England symbolically began with the arrival of 492 Jamaicans on the S.S. Empire Windrush in 1948. By 1958 about 125,000 West Indians had emigrated to England. Known today as the Windrush generation, they were British citizens who had left behind few job prospects in the post war Caribbean for the promise of a new life in the "Motherland." African Caribbean immigrants living in London in the 1950s found it difficult to find accommodations, were refused service in restaurants and pubs, and often worked 12-14 hours a day in difficult conditions for less than White workers (Walker \& Elcock, 1998). In the late 1960s the children of the Windrush generation were harassed by the British police through stop and search (SUS) policies and disproportionately placed in segregated special education programs, known as ESN (Educationally Subnormal) schools (Coard, 1971).

Black educational activism in London became very visible in the late 1960s when parents, community leaders, and educators organized rallies, signed petitions, and staged demonstrations against the banding and tracking of Black students and their overrepresentation in ESN schools and in-school detention classrooms known as "sin bins." Community groups such as the North London West Indian Association urged 
parents to "UNITE AND FIGHT FOR YOUR RIGHTS" (Haringuey Education Committee Flyer, 1969). Some of the earliest educational advocates for Black children in London were the "Island Scholars" and other Caribbean university students who came to Britain for graduate study. Ansel Wong, who had emigrated from Trinidad as a graduate student in 1965, organized a Black Theater Arts workshop at the West Indian Student Centre that performed Black-themed plays throughout London. He also coordinated the CLR James School, an early Black supplementary school that enrolled the children of the Centre's graduate students and their friends.

Adopting the motto "we are our own educators," Black community activists and educators in London established supplementary or Saturday Schools, which provided community-based education in the living rooms, churches, and meeting halls of African Caribbean neighborhoods like Haringey and Brixton (Jones, 1986). Gus John, the first Black Education Director in London and a supplementary school teacher in the 1980s, described the educational focus of these community-based sites:

We took a decision that the children needed to be given some assistance in forming positive identity. And that was really about telling them "You're Black people, but not Black people according to the image that's presented in all of these books that you have in your schools or in the media. Our history didn't begin in a slave ship. And therefore you need to know something about your ancestry and heritage."

Other supplementary schools with a Black cultural orientation sprang up in London throughout the 1970s. On January 1, 1974, Ansel Wong began the Ahfiwe School in a community center across the street from the Brixton police station. As a young English teacher in the London schools in the late 1960s, Wong became increasingly aware of the disengagement of Black students. He named the school "Ah Fi We" from the Jamaican patois, which he translates as "It is Ours" or "It is for Us." The name represented to both students and parents that "the language we speak is a language we should be proud of." The school was funded by the Inner London Education Authority (ILEA) through the Community Relations Council as part of a new initiative in the 1970s to improve race relations in Brixton.

A race equality director in the ILEA in the 1980s explained why Black parents established supplementary schools after "knocking [their] heads against a brick wall" for many years:

As schools [did] not want to engage with Black parents, Black parents were disenfranchised....The Supplementary schools did two things. They passed on that tradition of the rich cultural heritage, but they also tried to inspire young people so that they would be academically successful (in government schools).

Black educators who advocated for a multicultural and anti-racist curriculum gained a foothold in the ILEA in the late 1970s and early 1980s. For instance, Len Kwesi Garrison emigrated as a school-aged child with his family from Jamaica to London in 1954. A medical photographer by training, Garrison was also a poet, a curriculum developer, and a community-based historian focused on preserving the record of the Black presence in Britain. In 1975 Garrison negotiated with the ILEA for funding and resources to establish an independent, community-based project to 
develop African-Caribbean and Black British curriculum materials. The project, which became known as ACER (Afro-Caribbean Educational Resources), was launched in 1977 with financial support from Section 11 government funds targeted for the needs of immigrant children. Garrison produced several curriculum guides and teaching videotapes, provided professional development to scores of London teachers about African Caribbean culture and history, and sponsored the "Black Youth Annual Writing Awards" about the realities and experiences of young Black people growing up in Britain (Garrison, 1982; 1985).

Garrison advocated for curriculum materials that would support the ethnic identity development of Black youth and ground them in African and Caribbean history, as well as explicate the institutional racism they faced. With the abolishment of the ILEA in 1989 by former Prime Minister and staunch conservative Margaret Thatcher, anti-racist political initiatives were targeted and demonized (Tomlinson, 2008), and multicultural curriculum programs like ACER lost their funding. When Black communities across England erupted in violence in the summer of 1981, Garrison and other community activists argued that what Black youth needed was not further police surveillance, but a community institution with positive representations of Black history and culture. In an interview shortly before his death in 2003, Garrison explained his advocacy for a Black Cultural Archives:

We need our own archives where important acts and achievement of the past which are now scattered or pushed into the margins of European history can be assembled, where facts now presented as negative can be represented from our point of view as positive factors in our liberation. We also need a Black Archive as a monument, which would remind the indigenous population that we know what is good for ourselves and have earned the right to be in this country. (As cited in Zhana, 2006)

London activists like Ansel Wong and Len Garrison promoted Black cultural arts, Pan-African political movements, and anti-racist curriculum reform. Their educational activism spanned disciplinary boundaries and viewed the cultural and political education of Black youth as a community responsibility. They believed deeply in the value of Black self-definition, and their change efforts were spurred and influenced by racist violence, social and educational segregation and oppression, and government backlash to multicultural initiatives. As border crossers and boundary spanners dedicated to empowering Black youth, they worked for both systemic educational improvement and the grassroots creation of new community-based educational arenas.

\section{Toronto in the 1980s and 1990s}

Toronto's Black community dates from the city's earliest days as a colony. Black Loyalists who fought with the British came to Canada after the Revolutionary War, and African Americans escaping slavery as well as free Blacks emigrated north throughout the first half of the 1800s. By the mid 1850s there were about 1,000 Blacks in Toronto out of a total population of 47,000 . Toronto's Black community grew slowly during the 
first half of the twentieth century largely due to an unofficial policy that restricted Black immigration and formal immigration standards established in the late 1920s that gave preference to immigrants from a European background (Hill, 1984).

When racially-based criteria were removed in the 1960s, Black Torontonians confronted housing segregation, increasing police profiling of Black teenagers, and growing disillusionment with the school system. In response, they lobbied the school board to become more responsive to African Canadian students and developed Black self-help organizations to provide community-based educational services.

Keren Brathwaite and Lloyd McKell were part of the wave of African Canadians who immigrated to Toronto in the late 1960s. Brathwaite came to Toronto from Antigua to attend graduate school at the University of Toronto on a Commonwealth Scholarship in 1967, where she was politicized by the racism she encountered and the lack of access for Black students and other students of color at the university. She asserted:

I found out that access to education was dismal, especially to university education and to graduate education. That would be my first point of knowledge because I could see it. But in moving out into the community, and mixing with African Canadians who had been here, I began to be exposed to the weight and the depth of the lack of access in the public school system, employment, etc. The whole question of racism loomed. I met older Black Canadians who spoke about sitting at the backs of classrooms.

Brathwaite developed the Transitional Year Programme (TYP) at the University of Toronto with other graduate student activists to provide university access to Black and First Nations students, single mothers, and students from poor neighborhoods. When she became a mother she lobbied with other parents for changes in the Toronto school district. Braithwaite explained:

It hits you when one's own children start to attend school and you become part of a PTA (Parent Teacher Association) and you see first-hand many things. The exclusion in the curriculum....The needs unmet. We know we were sending bright kids and they had a sparkle in their eyes for education. I became very active in parent organizing along with a diverse group of parents.

As Co-Director of the newly formed Organization of Parents of Black Children (OPBC), Brathwaite and other parents met on November 28, 1985 with Toronto's Associate Director of Education to present their ongoing concerns: the high dropout rate of Black students, the lack of Black teachers, culturally biased IQ tests, low expectations for Black students, and teachers' lack of knowledge about Black culture and the history of Blacks in Canada.

As a result of this meeting, a Consultative Committee on the Education of Black Children was established whose membership included parents as well as school district officials such as Lloyd McKell to create a "place at the table" for Toronto's ethnic and cultural communities in deliberations about school reform. Lloyd McKell arrived from Trinidad and Tobago to study economics at the University of Toronto in 1967. Although he didn't originally plan to settle in Toronto, he found himself increasingly involved in programs to support recent immigrant youth from the Caribbean. He was recruited as a 
School-Community Relations officer in 1976 after serving as a program director at the Harriet Tubman Centre housed in the Oakwood-St. Claire YMCA. McKell would go on to head up the School-Community Relations Department for the Toronto School Board, where he helped organize three city-wide parent conventions at Central Technical High School which involved over 1,000 parents and championed the development of Heritage Language programs.

Keren Brathwaite attributes the success of such community-based efforts to the leadership of the parent activists:

The School Community workers were not calling the shots. The parents were. Very importantly the supports (from the school district) came in planning conferences, and so on. The parents had good respect for that group of workers. They worked with the community well. Probably too well for the Board.

Although the School-Community Relations Department was abolished in 1986 because it was deemed "too political" (McCaskell, 2005), McKell eventually rose in the ranks to become the Executive Officer for Student and Community Equity and the first school district official to support the establishment of a public Africentric ${ }^{4}$ elementary school in Toronto (Brown, 2005).

At the end of his professional career, McKell reflected on the focus of Black activism in the Toronto schools:

(It was) devoted towards changing the existing school system to make it more responsive, less Eurocentric, more inclusive in all aspects-to curriculum, to student engagement, to quality and diversity of programs, to employment equity, to promotion of people of color to positions of responsibility, to access to decision making (and) structures of the Board by minority groups and so on. It was changing the essential nature of the school system to make it truly inclusive... in which Black students, in particular, could see themselves centered, as much as any other student, within the school system.

As Keren Brathwaite noted upon his retirement, Lloyd McKell served as "the bridge between the people and the (school) board so the parents' and students' voices could be heard," (Fanfair, 2013).

These educational activists in Toronto developed a "both/and" strategy by working within (and against) the school system that was mainly governed by White educational leaders as well as developing culture-based organizations and Black professional groups that linked Black teachers with community concerns. Parent activists like Keren Brathwaite worked in tandem with progressive school officials like Lloyd McKell to establish Black consultative committees, promote Black history curricula, and advocate for the first Race Relations policy to be established in a major North American school district (Minutes of the Board of Education, 1978). They used their social capital to establish insider-outsider coalitions and consultative structures for families from diverse neighborhoods as equal partners and leaders. 


\section{Detroit in the 2000s}

Black presence in the United States dates back to the early 1600s when the first African slave ships arrived and Africans were forcibly sold to Northeastern and Southern landowners (Bennett, Jr., 1988). The vast majority of African Americans lived in the South until the mid-20 $0^{\text {th }}$ century (Tavernese \& Gebeloff, 2011). During an era referred to as the Great Migration, from approximately 1910 to the 1940s, the population of Black/African American communities soared in large cities throughout the Northern and Midwestern United States, as those regions experienced financial boom and industrialization. The city of Detroit, Michigan, was at the forefront of such trends (Sugrue, 2005; Tavernese \& Gebeloff, 2011).

Commonly called the "Motor City," Detroit is where the world's automobile industry was founded. At its height in 1940s, Detroit was an economically thriving, racially diverse city of two million people with well performing schools. Soon after War World II, the city also implemented progressive intercultural and anti-bias educational policies to serve its multiethnic population (Halvorson \& Mirel, 2012) - a high contrast to the racially segregated schools in other parts of the country that had zero tolerance for racial mixing or multiculturalism. Still, Detroit became a hotbed of racial, social, and labor activism from the 1940s through the 1960s, as Black residents faced labor discrimination, housing exclusion, and everyday racism (Sugrue, 2005).

Today, Detroit is a city of approximately 700,000 people with a population that is nearly 83\% African American/Black (U.S. Census Bureau, n.d.). The city has been devastated by severe poverty and the loss of 1.3 million residents over the past several decades, most of whom were middle class and provided a large tax base to fund high quality public services and schools (Sugrue, 2005). Now, over a third of Detroiters experience poverty, and most city youth attend extremely low performing and underresourced schools (Pedroni, 2011). Since local property tariffs greatly contribute to how U.S. schools and cities are funded, Detroit's population loss has resulted in physical, educational, and civic infrastructures that city officials are unable to fiscally support (Pedroni, 2011; Sugrue, 2005.) At the same time, high levels of poverty and crime, political corruption, and city-wide bankruptcy have injured the city's reputation (Davey \& Walsh, 2013). The fact that these hardships exist in a predominantly Black city contributes to the perpetuation of what Pedroni (2011) calls a "dominant racially-coded narrative" in the media and a popular culture that is xenophobic and often racist, while ignoring the vibrancy, goodness, and resiliency of the city and its residents.

While Detroit continues its struggle towards economic renewal, most of its schools remain in dire condition, including traditional public schools and a plethora of choice-oriented, market-based charter schools (Pedroni, 2011). Many schools lack adequate equipment, facilities, and highly qualified and experienced teachers (Higgins, 2014). The State of Michigan appointed an "emergency manager" in 2009 who is vested with a great deal of authority to lead the city's beleaguered school district rather than relying on the democratically elected school board. A controversial state-run entity called the Educational Achievement Authority (EAA) has also controlled 15 of the city's 
lowest performing public schools since 2011 (Higgins, 2014). In addition, over 200 Detroit public schools have been closed in the past 15 years due to population loss, dilapidation, and the choices of state and school district authorities, despite Black community members' protest over the closures (AlHajal, 2013).

The African American educational activists who participated in the Detroit study pointed to the aforementioned conditions as key to their activism efforts. Their data also indicate the micro- to macro levels of racial oppression they strive to contest -- from the demeaning ways they are spoken to by some public officials to the privatizing, nondemocratic school reform climate that ill serves Black families. Helen Axelrod began advocating for her autistic nephew and soon expanded the scope of her activities to advocate for the rights of other children with disabilities at a range of school-wide and district-wide meetings held in the Detroit Public Schools (DPS) system. ${ }^{5}$ She was eventually elected to represent a parent/family-based educational group in Detroit. Ms. Axelrod has participated in public protests and testified in front of state legislators, stressing the rights and needs of DPS students and contesting the closure of inner-city schools. She discussed her commitment to inform other DPS family members, nurture their trust, and encourage their advocacy. Ms. Axelrod explained that "Michigan is notorious as a state for its hostility" toward Black communities. She described herself as "outraged" at times, given racism, the educational inequity she has observed within DPS, and, as she asserts, the "human rights" violation of children with special needs.

For instance, Ms. Axelrod described how she became disgusted with the conditions of a new school for students with disabilities (who were almost all African American), which was opened with faulty electrical wiring after an older school serving the same students was closed due to its inadequate facilities. She stated, "I got the city council involved. Made calls to the mayor, environmental agency, the Feds, civil rights office, health inspectors, fire marshals, (the) American Disability Act people, whomever. I filed the civil rights complaint."

Other aspects of her activism entailed challenging the racist ideologies of some state legislators. She explained:

Racism shows up when we're at certain meetings. It shows up in the terms of some White privileged folks saying things like: "Well aren't those people in Detroit double dipping off the government-they're collecting government money at the schools? They get free lunches. Isn't that called double and triple dipping?" To me, that is a racist statement. First, you said "those people in Detroit."...Not everyone in Detroit is on welfare. I can pull up all the (government assistance) statistics in the State of Michigan and most (welfare recipients) are White people living in the farmlands of Michigan. When racism shows up, I have to address it immediately. People talk to me like I'm one of the ignorant, stereotypes in their head.

Ms. Axelrod said, in response, that she confronts people and will say something like: "You just made a racist statement to me, and this is how you did it... You need to check yourself. You can't speak to me or anyone else that way. You can't do that!"

Ms. Axelrod further stressed that her activism involves political risks, emotional turmoil, and financial sacrifices, yet affirmed her commitment to "promoting the positive 
things." She said her efforts "would fall right into the history with the struggle that is ongoing in Detroit," and "my reward is thinking I am part of that history."

Ms. Gladys Sails is a former DPS parent and teacher turned political representative and educational activist. Ms. Sails explicitly identified her activism as being part of a "grassroots" tradition that encompasses "people who have a commitment to a core right for social justice, and are not looking for a way to profit from that, but volunteer their time (and) their capacity to work with others towards fighting injustice." She talked of being inspired by the work of distinguished African American leaders like Dr. Martin Luther King, Jr. and former U.S. Congresswoman Shirley Chisholm.

Ms. Sails has been dedicated to challenging what she characterized as the "privatization" of DPS given the sharp rise of for-profit charter schools that are hard for most poor Black Detroit families to financially and logistically access-schools that were once traditional public schools. She contended that she strives to "build relationships and alliances to push back on the move or the agenda that they (pro-privatization officials and corporate interests) have, which often entails lobbying and challenging prominent, upper income, White authorities." Ms. Sails asserted:

Typically what the corporate mindset tries to do is minimize the relevance of a grassroots person and their expertise or knowledge base...to discredit the person [as] just ranting and raving for nothing.... Being able to use my level of knowledge base to advocate in a way that does not give them that room to dismiss someone [as] not knowing - that's been one of the biggest pieces of accomplishment....It takes a lot of courage to walk in the same room and setting to people who are getting $\$ 100,000$ plus a year. [I] have to demonstrate that I am just as qualified and just as good as you are-to be able to have the knowledge base and really deflect the narrative they are putting out.

The "narrative" that Ms. Sails mentioned refers to ideas that Detroit's predominantly public schools can only be improved by outside-corporate takeover versus communitybased initiatives.

Other Detroit activists interviewed in this study include Ms. Solomon, an active DPS parent volunteer turned non-profit organization leader. She advocates for various school choice options in DPS, including charter schools. Ms. Solomon explained that though she partners with DPS and other nearby school districts, her primary goal is to empower Detroit parents. She explained:

We help parents navigate issues when they have problems with their child who has special needs....we help parents build their leadership skills and be able to be a voice and advocate. We are part of every major education reform effort that is underway in the city right now, as far as making sure that parent voice, perspective, concerns, hopes, and fears are communicated at those decisionmaking tables, and working to make sure we help put parents in those leadership positions as well.

When referring to controversial debates over DPS school choice reforms, Ms. Solomon maintained that she and her colleagues have "intentionally planted ourselves in the 
conversation" to help hold educational officials accountable since "the money we invest in our kids pays the salaries of everybody sitting at these tables...."

While Ms. Axelrod, Sails, and Solomon have engaged in many public protest strategies commonly associated with political activism, several other Detroit study participants used alternative forms of political resistance, including a principal who adopted an Afrocentric curriculum when it was unpopular and risky to do so, and a former school social worker who now provides anti-racism workshops in schools. In all, they are activists who stressed the value of Black children. As current DPS teacher Ms. Shah stated, the activists "know the talent we have in this city, [and] know the injustices in education [and] how it hinders that talent." Their activism reflects Ms. Shah's recommendation that "the first thing we need to do is make the village a part of the schools again." This statement pertains to the African proverb that "it takes a village to raise a child." It also resonates with the Detroit activists' belief in collective racial uplift and an ethic of critical care that counters the individualistic ideologies, policies, and practices of the United States that disadvantage Black children.

\section{Discussion and Recommendations}

Black educational activism has emerged as a form of leadership through which public citizens and community members effect institutional and systemic change and engage in valuable democratic practice. They do so by voicing educational needs, ideas, and concerns related to youth in their communities and strategizing to promote educational improvement while countering oppressive organizational, instructional, and political dynamics. They also work to hold public officials and educators (who are sometimes their peers or supervisors) accountable for providing the high quality, equitable educational services they are charged with offering. Given the four findings from our comparative data, we briefly suggest some epistemological, relational, structural, and practical implications that can inform future research development and the practice and preparation of K-12 educational leaders, with a particular focus on making public school systems more inclusive, culturally responsive, and equitable.

From an epistemological standpoint, the Black educational activists studied in London, Toronto, and Detroit possess distinct knowledge and perspectives about the impact of education and reform that can greatly inform educational improvement efforts. Yet, as highlighted in the Detroit data, their knowledge is too often overlooked, questioned, or "discredited" within dominant educational reform circles. It is imperative that educators and reformers do more to validate experiential knowledge and relevant community-based and/or professional expertise. Such knowledge pertains to our first finding about the activists' racial consciousness and their acute understanding of how race influences micro-to-macro level educational injustice, thereby motivating their political resistance.

As part of their political resistance, activists in each city have traversed various ideological, communal, institutional, and political domains to build relationships and assert their agendas. As the Toronto data emphasized, they often serve as a "bridge" 
between families, schools, and communities. Their various roles affirm our second finding about them serving as border crossers and boundary spanners (Giroux, 2005; Miller, 2007, 2008, 2009; Wilson, Ek, \& Douglas, 2014). The various strategies they use to influence structural change relate to the last two findings. Data from each city showed that activism occurs at community-based grassroots levels and within institutional levels. Indeed, the activists we studied who were vested with positional authority also challenged the dominant educational system.

Overall, whether parent, community member, teacher, principal, or political representative, contesting racism and inequitable educational systems has felt to some activists like their head was "against a brick wall," as stressed in the London data. Still, study participants persisted and have been influential through developing and wielding important social capital through building relationships and networks in various arenas and marshaling their knowledge, skills, contacts, energy, creativity, and savvy to uplift and empower others.

Efforts to counter the structural oppression that educational inequity yields have encompassed demanding inclusion, fair representation, and educational responsiveness, and our data highlight such work as a transnational struggle. Black educational activism, therefore, is an inherently democratic practice that should be valued rather than squelched. Activism is key for equity accountability for Black communities throughout the African Diaspora. Such accountability moves beyond merely desiring higher student test scores to insisting that educators and policymakers justly serve their communities and constituents (Noguera, 2005). It also involves guaranteeing that Black community members have "a place at the table" when important decisions are being made.

Finally, we recommend that the perspectives, efforts, and contributions of educational activists be emphasized in educational leadership preparation. Aspiring school leaders would benefit from having the strategies and experiences of activists who lead change in diverse communities incorporated in their course readings, as well as participating in community-based, political experiential internships and curricular activities that require them to engage with diverse families and communities in civic forums. These internships might include apprenticing with school leaders who are deeply connected to local communities as well as other field-based experiences where they work under the guidance of parents and neighborhood leaders. To be most effective, these internships should be coupled with seminars where aspiring school leaders can dialogue and critically reflect on how their experiences intersect with issues of race, culture, and power (Auerbach, 2009; Cooper, 2009).

Activists in each of the three locales we studied shared their desire to forge better relationships with $\mathrm{K}-12$ educational administrators and policymakers to improve schools. Generally, however, they were not held in the same high regard. We believe these emotionally invested, equity-oriented, insightful, and skilled community members should be welcomed into schools and reform circles as leadership partners. 


\section{Notes}

1. Here we are defining leadership as the process of a person or group motivating and mobilizing others to change their thoughts and/or activities to achieve a shared goal (Alston \& McClellan, 2011).

2. A more detailed account of the Detroit study, which Kaleema Annie Sumareh assisted with, will be discussed in a 2015 forthcoming article by the first author in Educational Policy Analysis Archives.

3. In addition to the scholars we have cited, see the work of those like Derrick Bell, Haroon Kharem, bell hooks, Joy James, Karen Johnson, and Charles Payne, who have advanced notions of Black activism in their theoretical and historical work.

4. Toronto activists use the term, "Africentric," rather than "Afrocentric," as they assert the spelling more closely represents an African-centered approach.

5. Names of Detroit study participants are pseudonyms.

\section{References}

AlHajal, K. (2013, May 15). Closure of school that serves disabled students protested; District says it would cost too much to keep open. MLive. Retrieved from http://www.mlive.com/news/detroit/index.ssf/2013/05/closure of school that serves.html

Alston, J. A. (2005). Tempered radicals and servant leaders: Black females persevering in the superintendency. Educational Administration Quarterly, 41(4), 675-688.

Alston, J. A., \& McClellan, P. A. (2011). Herstories: Leading with lessons of the lives of Black women activists. New York, NY: Peter Lang Publishing.

Auerbach, S. (2009). Walking the walk: Portraits in leadership for family engagement in urban schools. The School Community Journal, 19(1), 9-31.

Bennett, Jr., L. (1988). Before the Mayflower: A history of Black America. Chicago, IL: Johnson Publishing Company.

Brown, L. (2005, September 14). Black only school proposed; All-black school touted for Toronto. Race-based classes touted for teens. New equity boss says it could work. The Toronto Star, p. A.01.

Coard, B. (1971). How the West Indian child is made educationally subnormal in the British school system: The scandal of the Black child in schools in Britain. London, UK: New Beacon Books.

Collins, P. H. (1990). Black feminist thought: Knowledge, consciousness, and the politics of empowerment. New York, NY: Routledge. 
Cooper, C. W. (2009). Performing cultural work in demographically changing schools: Implications for expanding transformative leadership frameworks. Educational Administration Quarterly, 45(5), 694-724.

Creswell, J. (2008). Research design: Qualitative, quantitative, and mixed methods approaches (3rd ed.). Thousand Oaks, CA: Sage.

Dantley, M. E., \& Tillman, L. C. (2009). Social justice and moral transformative leadership. In C. Marshall \& M. Oliva (Eds.), Leadership for social justice: Making revolutions in education, 2nd edition (pp. 19-34). Boston, MA: Allyn \& Bacon Publishers.

Davey, M., \& Walsh, M. W. (2013, July 18). "Billions in debt, Detroit tumbles into insolvency." New York Times. Retrieved from http://www.nytimes.com/ 2013/07/19/us/detroit-files-for-bankruptcy.html

Dillard, C. B. (1995). Leading with her life: An African American feminist (re)interpretation of leadership for an urban high school principal. Educational Administration Quarterly, 31(4), 539-563.

Fanfair, R. (2013, October 14). Lloyd McKell praised as an education equity pioneer. Share. Retrieved from http://sharenews.com/archives/20110223lloyd-mckell-praisededucation-equity-pioneer/

Franklin, V.P. (1990). "They rose and fell together": African American educators and community leadership, 1795-1954. Journal of Education, 172(3), 39-64.

Garrison, L. (1982). Resources for anti-racist education. London, UK: ACER Centre.

Garrison, L. (1985). Resources for education in a plural society: Policy to practice. London, UK: ACER Centre.

Giroux, H. A. (2005). Border crossings (2nd ed.). New York, NY: Routledge.

Halvorson, A., \& Mirel, J. (2012). Intercultural education in Detroit, 1943-1954. Paedagogica Historica: International Journal of the History of Education, 49(3), 361 - 381.

"Haringey Education Committee Flyer," (1969, April 2). London, UK: George Padmore Institute.

Henry, A. (2005). Black feminist thought: Critiques and contributions. In W. H. Watkins (Ed.), Black protest thought and education (pp. 89 - 105). New York, NY: Peter Lang.

Higgins, L. (2014, June 28). "In Detroit, quality schools still elusive." Detroit Free Press. Retrieved from http://archive.freep.com/article/20140628/NEWS06/306280026/ Detroitcharter-schools

Hill, D. G. (1984). Black history in early Toronto. Polyphony 6, 28 - 30.

Honig, M. (2006). Street level bureaucracy revisited: Frontline district central office administrators as boundary spanners in educational policy administration. Educational Evaluation and Policy Analysis, 28(4), 357-383. 
Jean-Marie, G., Williams, V. A., \& Sherman, S.L. (2009). Black women's leadership experiences: Examining the intersectionality of race and gender. Advances in Developing Human Resources, 11(5), 562-581.

Jemison, D. B. (1984). The importance of boundary spanning roles in strategic decision-making. Journal of Management Studies, 21(2), 131-152.

Johnson, L. (2006). "Making her community a better place to live": Culturally responsive urban school leadership in historical context. Leadership and Policy in Schools, 5(1), 19-36.

Johnson, L. (2013). Segregation or "thinking Black"? Community activism and the development of Black-focused schools in Toronto and London, 1968 - 2008. Teachers College Record, 115(11), 1-25.

Jones, V. A. (1986). We are our own educators! Josina Machel: From supplementary to Black complementary school. London, UK: Karia Press.

Loder-Jackson, T.L. (2011). Bridging the legacy of activism across generations: Life stories of African American educators in post-civil rights Birmingham. The Urban Review, 43(2), 151-174. doi 10.1007/s11256-009-0142-1

Marshall, C., \& Anderson, A. L. (2009). Is it possible to be an activist educator? In C. Marshall \& A. L. Anderson (Eds.), Activist educators: Breaking past limits (pp. 130). New York, NY: Routledge.

McCaskell, T. (2005). Race to equity: Disrupting educational inequality. Toronto, Canada: Between the Lines Press.

McKittrick, K., \& Woods, C. (Eds.) (2007). Black geographies and the politics of place. Toronto, Canada: Between the Lines Press.

Miller, P. M. (2007). Examining boundary spanning leadership in university-schoolcommunity partnerships. Journal of School Public Relations, 28(2), 189-211.

Miller, P. (2008). Examining the work of boundary spanners within community contexts. International Journal of Leadership in Education: Theory and Practice, 11(4), 353-377.

Miller, P. (2009). Boundary spanning in homeless children's education: Notes from an emergent faculty role in Pittsburgh. Educational Administration Quarterly, 45(4), 616-630.

Minutes of the Board of Education (November 23, 1978). Toronto, Canada: Toronto Board of Education, p. $1099-1118$.

Murtadha, K., \& Watts, D. M. (2005). Linking the struggle for education and social justice: Historical perspectives of African American leadership in schools. Educational Administration Quarterly, 41(4), 591-608.

Noguera, P. (2005). The racial achievement gap: How can we assure an equity of outcomes? In L. Johnson, M. Finn, \& R. Lewis, (Eds.), Urban education with an attitude (pp. 11 - 20). Albany, NY: State University of New York Press. 
Pedroni, T. C. (2011). Urban shrinkage as a performance of whiteness: Neoliberal urban restructuring, education, and racial containment in the post-industrial, global niche city. Discourse: Studies in the Cultural Politics of Education, 32(20), 203-215. doi:10.1080/01596306.2011.562666

Perlstein, D. (2005). Minds stayed on freedom: Politics and pedagogy in the African American freedom struggle. In W. H. Watkins (Ed.), Black protest thought and education (pp. 33-66). New York, NY: Peter Lang.

Richards, S., \& Lemelle, S. J. (2005). Pedagogy, politics, and power: Antinomies of the Black radical tradition. In W. H. Watkins (Ed.), Black protest thought and education (pp. 5-31). New York, NY: Peter Lang.

Shields, C. M. (2000). Learning from difference: Considerations for schools as communities. Curriculum Inquiry, 30(3), 275-294.

Shoho, A. R., Merchant, B. M., \& Lugg, C. A. (2005). Social justice. In F. W. English (Ed.), The Sage handbook of educational leadership: Advances in theory, research, and practice (pp. 47-67). Thousand Oaks, CA: Sage.

Stanton-Salazar, R. D. (2011). A social capital framework for the study of institutional agents and their role in the empowerment of low-status students and youth. Youth and Society, 43(3), 1066-1109.

Sugrue, T. J. (2005). The origins of the urban crisis: Race and inequality in postwar Detroit (Revised ed.). Princeton, NJ: Princeton University Press.

Tavernese, S., \& Gebeloff, R. (2011, March 24). Many US Blacks moving to South, reversing trend. New York Times. Retrieved from http://www.nytimes.com/ 2011/03/25/us/25south.html?pagewanted=all\& $r=0$

Tomlinson, S. (2008). Race and education: Policy and politics in Britain. Maidenhead, UK: Open University Press.

Tushman, M. L. (1977). Special boundary roles in the innovation process. Administrative Science Quarterly, 22(4), 587-605.

U.S. Census Bureau, (n.d.). State and county quickfacts. Retrieved from http://quickfacts.census.gov/qfd/states/26/2622000.html

Walker, S., \& Elcock, A. (1998). The Windrush legacy: Memories of Britain's post-war Caribbean immigrants. Lambeth, UK: Black Cultural Archives.

Watkins, W. H. (2005). Introduction. In W. H. Watkins (Ed.), Black protest thought and education (pp. 1-4). New York, NY: Peter Lang.

Williams, A. H. (2009). The fight of their lives: African American activist educators. In C. Marshall \& A. L. Anderson (Eds.), Activist educators: Breaking past limits (pp. 3150). New York, NY: Routledge.

Williamson, J. (2005). Community control with a Black nationalist twist: The Black Panther Party's educational programs. In W. H. Watkins (Ed.), Black protest thought and education (pp. 137 - 158). New York, NY: Peter Lang. 
Wilson, C. M., Douglas, T. M. O., \& Nganga, C. (2013). Starting with African American success: A strengths-based approach to transformative educational leadership. In L. C. Tillman \& J. J. Scheurich (Eds.), Handbook of research on educational leadership for equity and diversity (pp. 111-133). New York, NY: Routledge.

Wilson, C., Ek, L. D., \& Douglas, T. M. O. (2014). Recasting border crossing politics and pedagogies to combat educational inequity: Experiences, identities, and perceptions of Latino/a immigrant youth. Urban Review, 46, $1-24$.

Zhana (2006). Len Garrison/Black Cultural Archives. In Black success stories: Volume 1: Celebrating people of African heritage. Retrieved from http://www. publicbookshelf.com/biography/black-success/len-garrison

\section{Author Contact}

Camille Wilson (corresponding author): camillew@umich.edu

University of Michigan, Department of Educational Studies, 610 East University Avenue, Ann Arbor, MI 48109, U.S.A.

Lauri Johnson: lauri.johnson@bc.edu

Boston College, Department of Educational Leadership and Higher Education, 205C Campion Hall, Chestnut Hill, MA 02467, U.S.A. 